\title{
Determination of Advanced Oxidation Protein Products, E3 SUMO-Protein Ligase NSE2[NSMCE2], as a Marker to Predict Child Acute Lymphoblastic Leukemia
}

\author{
Alaa Shawqi Abdulbari*
}

Wesen Adil Mehdi*

\author{
Received 14, April, 2013 \\ Accepted 12, September, 2013
}

\begin{abstract}
:
Acute lymphoblastic leukemia (ALL) is a cancer of the blood and bone marrow (spongy tissue in the center of bone). In ALL, too many bone marrow stem cells develop into a type of white blood cell called lymphocytes. These abnormal lymphocytes are not able to fight infection very well. The aim of this study was to investigate possible links between E3 SUMO-Protein Ligase NSE2 [NSMCE2] and increase DNA damage in the childhood patients with Acute lymphoblastic leukemia (ALL). Laboratory investigations including hemoglobin $(\mathrm{Hb})$, white blood cell (WBC) , serum total protein, albumin ,globulin, in addition to serum total antioxidant activity (TAA), Advanced oxidation protein products(AOPP) and E3 SUMO-Protein Ligase NSE2[NSMCE2]. Blood samples were collected from 60 patients diagnosed to Acute lymphoblastic leukemia (ALL) after one month treatment with induction therapy. Age and sex matched 30 healthy persons selected as control.

serum total protein, albumin and globulin showed A significant decrease in patients group when compared to control group $(\mathrm{P}<0.01, \mathrm{P}<0.05$ and $\mathrm{P}<0.05)$ respectively, total antioxidant activity (TAA) showed A significant decrease in patients group when compared to control group $(\mathrm{P}<0.001)$, while AOPP,NSMCE2, showed a significant increase in patients group in comparison to control group $(\mathrm{P}<0.001)$. Conclusions: The results from this study showed a significant increase in NSMCE2, AOPP, NSMCE2 /TAA ratio, NSMCE2/S. protein ratio and AOPP/ S.Protein ratio. These results in the present study are shown for the first time to the best of our knowledge. These parameters may play a role in developments of change DNA damage in the childhood patients with Acute lymphoblastic leukemia (ALL)
\end{abstract}

Key words: Acute lymphoblastic leukemia (ALL) , NSMCE2,AOPP, total antioxidant activity.

\section{Introduction:}

The leukemia defined as a group of malignant diseases in which progeny of the cells have a growth advantage over normal cellular elements owing to an increased rate of proliferation with decreased rate of normal marrow function and ultimately marrow failure[1] .These abnormal cells cause symptoms because of bone marrow failure(i.e. anemia, neutropenia, thrombocytobenia) and infiltration of organs (e.g. liver, spleen, lymph

nodes). The great majority of childhood leukemia's of the acute type, acute lymphoblastic leukemia (ALL) comprising $80-85 \%$ of childhood cases and acute myeloid leukemia (AML) 10-15\% [2].Acute leukemia is characterized by the rapid increase of immature blood cells. This crowding makes the bone marrow unable to produce healthy blood cells.Immediate treatment is required in acute leukemias due to the rapid progression

*Department of chemistry, College of Sciences for Women, University of Baghdad, Iraq 
and accumulation of the malignant cells, which then spill over into the bloodstream and spread to other organs of the body. Acute forms of leukemia are the most common forms of leukemia in children.[3].Acute lymphoblastic leukemia (ALL) is the most common pediatric cancer[4]. The etiology of this hematologic malignancy might be explained by a combination of genetic susceptibility and environmental exposure during early development in fetal life and infancy. Assuming that genes modulate individual responses to exogenous and/or endogenous factors, they would thereby also influence an individual's risk of cancer. Consistent with this paradigm, it has been shown that childhood leukemogenesis is associated with genetic variability in xenobiotic metabolism, oxidative stress response and DNA repair [5].Clinical manifestations at presentation include constitutional symptoms (fevers, night sweats, weight loss), easy bruising or bleeding, dyspnea, dizziness, and infections. Extremity and joint pain may be the only presenting symptoms[6].

Advanced oxidation protein products (AOPPs) are a new marker of oxidative damage, valued for their ease of determination and stability [7].AOPPs result from the action of chlorinated compounds on proteins, leading to the formation of dityrosine residues and consequently to the protein cross-linking, aggregation and precipitation [8].Except for being the effect of oxidative imbalance, AOPPs are involved in the further development of oxidative stress and inflammation by the activation of immune cells[9].Accumulation of AOPPs has been reported in various pathologies[8],also those associated with impaired carbohydrate metabolism[10, 11].
The small ubiquitin-like modifier (SUMO) is covalently linked to a variety of proteins and is de conjugated by SUMO-specific proteases. A characteristic of SUMO modification is that the biological consequences of conjugation do not appear proportionate to the small fraction of substrate that is modified [12].The small ubiquitin-like modifier (SUMO) conjugation to target proteins involves a cascade of enzymatic activities composed of the heterodimeric SUMO-activating E1 enzyme (Aos1/Uba2), the SUMOconjugating E2 enzyme (Ubc9), and a SUMO E3 ligase that increases the efficiency of SUMO conjugation[13].The E3 SUMOProtein ligase NSE2 (NSMCE2)Alternative name(s):MMS21 homolog. The E3 SUMO-protein ligase component of the SMC5-SMC6 complex, a complex involved in DNA double-strand break repair by homologous recombination. Is not be required for the stability of the complex. The complex may promote sister chromatid homologous recombination by recruiting the SMC1SMC3 cohesin complex to doublestrand breaks. The complex is required for telomere maintenance via recombination in ALT (alternative lengthening of telomeres) cell lines and mediates sumoylation of shelterin complex (telosome) components which is proposed to lead to shelterin complex disassembly in ALTassociated PML bodies (APBs). Acts as a E3 ligase mediating SUMO attachment to various proteins such as SMC6L1 and TRAX, the shelterin complex subunits TERF1, TERF2, TINF2 and TERF2IP, and may be the cohesin components RAD21 and STAG2. Required for recruitment of telomeres to PML nuclear bodies. SUMO protein-ligase activity is required for the prevention of DNA 
damage-induced apoptosis by facilitating DNA repair, and for formation of APBs in ALT cell lines. Required for sister chromatid cohesion during prometaphase and mitotic progression[14-17].

The aim of the current study was to determine the level of Serum E3 SUMO -Protein ligase NSE2(NSMCE2) and AOPP in child with ALL after one month treatment with induction therapy, and study the correlation between these biochemical parameters .

\section{Materials and Methods:}

Blood samples were collected from 60 patients diagnosed to Acute lymphoblastic leukemia (ALL) as they were submitted to the Protection of Children Hospital Medical City in Baghdad, Iraq. The diagnosis for ALL based on the following findings: leukocyte count, age, involvement of tissues other than bone marrow. Age and sex matched 30 healthy persons who are devoid of conditions like diabetes mellitus, epilepsy, psychiatric disorders or history of any drug intake are selected as control. Five $\mathrm{ml}$ of venous blood was drawn from (60) patients of ALL ranging between (116) years old ,after one month induction therapy treatment and normal control. The blood was allowed to clot for at least 10-15 min. at room temperature, centrifuged for (10) $\mathrm{min}$. at $(4000 \mathrm{xg})$. Serum was removed and divided into two parts the first to measure the biochemical parameters and the other part was stored at $-18^{\circ} \mathrm{C}$ until the time of AOPP and NSMCE2 assay. Serum total protein was determined by Lowry et. al. method[18] using bovine serum albumin (BSA) as a standard protein. Serum albumin concentration was measured by Rodkey method[19] (bromocresol green binding) using RANDOX kit. Serum globulin concentration was determined mathematically from the subtraction the value of albumin concentration from that of total protein. The concentration of albumin divided by the concentration of globulin was expressed as albumin to globulin ratio. Total antioxidant activity (TAA) in serum samples was carried out according to Rice -Evans and Miller [20]. The serum AOPP and NSMCE2 were measured by Enzyme Linked Immunosorbent (ELISA)(CUSABIO Assay COM.)

All statistical analyses in studies were performed using SPSS version 17.0 for Windows (Statistical Package for Social Science, Inc., Chicago, IL, USA). Descriptive analysis was used to show the mean and standard deviation of variables. The significance of difference between mean values was estimated by Student T-Test. The probability $\mathrm{P}<0.05=$ significant, $\mathrm{P}>$ $0.05=$ non-significant. Correlation analysis was used to test the linear relationship between parameters .ANOVA test was used to show the differences between variables of differentiated groups

\section{Results and Discussions:}

A total of 60 of child with ALL were included in the present study. All patients were matched for age 1-16 years [50\% (1-8 year),50\%(9-16 year )] and sex was divided into[31 male, $51.67 \%$ ] and [29 female, $48.33 \%$ ], all patients were matched for age 5-11 years and sex was divided into $50 \%$ male \& $50 \%$ female. The demographic and the hematological data of ALL patients and control are shown in Table 1. It was found that the levels of WBCs were significantly elevated in diagnosed leukemic patients compared to control group $(\mathrm{P}<0.01)$, while $\mathrm{Hb}$ 
was significantly decreased $(\mathrm{P}<0.001)$ Table 1.

The current study showed that there were no significant different in $\mathrm{Hb}$ and WBC between male and female patient or when divided patients group according age in two group (18year )and (9-16 year).

Table (1): Demographic and hematological data of different studied groups (Mean \pm SD)

\begin{tabular}{|r|c|c|l|}
\hline Characteristic & $\begin{array}{r}\text { Patients } \\
\text { group[n=30] }\end{array}$ & $\begin{array}{r}\text { Control } \\
\text { group[n=3 }\end{array}$ & $\begin{array}{l}\text { P } \\
\text { Value }\end{array}$ \\
\hline Age [year] & $7.98 \pm 3.41$ & $7.20 \pm 3.84$ & $>0.05$ \\
& & $11.68 \pm$ & $<0.00$ \\
& 0.69 & 1 \\
\hline $\mathrm{Hb}[\mathrm{g} / \mathrm{dl}]$ & $9.27 \pm 1.40$ & $38.02 \pm 2.00$ & $<0.00$ \\
& & & 1 \\
\hline PCV \% & $29.95 \pm 4.92$ & $6.87 \pm 0.8$ & $<0.01$ \\
\hline WBC*10 ${ }^{3}$ cell/ & $9.88 \pm 0.43$ & \multicolumn{2}{|l}{ level } \\
\hline
\end{tabular}

*Significant at 0.05 level of significance

Increase level of WBC is One of characteristics of leukemia [21], As a result of the uncontrolled growth of leukemic cells in the bone marrow, there is inadequate space in the bone marrow for normal blood production (hematopoiesis) to occur. The lack of normal blood growth results in the lack of normal white blood cells (increasing the risk of infection), the lack of red blood cells (resulting in fatigue, weakness, and anemia) and the lack of normal platelet production (increasing the risk of bleeding).[22]

Hemoglobin was found statistically significant to be decreased in ALL patients compared to controls. Anemia is a frequent finding in patients with hematologic malignancies, such as acute leukemia or malignant lymphoma. The anemia is caused by a variety of mechanisms, including neoplastic cell infiltration into bone marrow(BM),nutritional deficiencies, and defects in erythropoietin as a result of the disease itself [23]. Bleeding in acute leukemia usually results from thrombocytopenia involving the skin and mucus membranes and may or may not correlate degree of thrombocytopenia as platelet dysfunction may also be present.[24]

The mean levels of sera protein , albumin and globulin showed A significant decrease in patients group when compared to control group( $\mathrm{P}<0.01, \mathrm{P}<0.05$ and $\mathrm{P}$ $<0.05)$ respectively , while Alb/Glb ratio showed a significant increase in patients group in comparison to control group $(\mathrm{P}<0.01)$ as shown in table 2 .

Table (2): The mean and standard deviation of serum protein, albumin, globulin, Alb/Glb in patients group and control

\begin{tabular}{|c|c|c|c|}
\hline Characteristic & $\begin{array}{c}\text { Patients } \\
\text { group[n=60] }\end{array}$ & $\begin{array}{c}\text { Control } \\
\text { group } \\
{[\mathbf{n = 3 0 ]}}\end{array}$ & $\begin{array}{c}\text { P } \\
\text { Value }\end{array}$ \\
\hline $\begin{array}{c}\text { T.S. } \\
\text { Protein[g/dl] }\end{array}$ & $6.29 \pm 1.07$ & $7.00 \pm 0.66$ & $<0.01$ \\
\hline $\begin{array}{c}\text { S. Albumin } \\
\text { [g/dl] }\end{array}$ & $4.10 \pm 0.65$ & $4.38 \pm 0.38$ & $<0.05$ \\
\hline $\begin{array}{c}\text { S. Globulin } \\
\text { [g/dl] }\end{array}$ & $2.20 \pm 0.81$ & $2.61 \pm 0.46$ & $<0.05$ \\
\hline Alb./Glb. ratio & $2.63 \pm 1.57$ & $1.63 \pm 0.19$ & $<0.01$ \\
\hline
\end{tabular}

*Significant at 0.05 level of significance

The current study showed that there were no significant different in serum protein , albumin, globulin and Alb/Glb between male and female patient or when divided patients group according age in two group (1-8year )and (9-16 year).

Serum proteins are useful indicators for initial screening of any abnormal function, inflammation and diseased condition. The expression of different proteins can vary depending on the age of the person [21]

In these studies, results indicate a decrease in serum protein and this is consistent with other studies of [25, 26]

Acute protein loss is generally due to reduced protein intake coupled with a hypermetabolic state resulting in 
rapid depletion of visceral proteins. This combined mechanism may explain the reduced levels of albumin observed in $1 / 3$ children at diagnosis.[25]

In the present study, results indicate a decrease in serum albumin and this is consistent with the other studies[21, 25,26,27],but disagreement with [28]

The decreased albumin level results either from depressed synthesis or increased losses of albumin. A decrease in albumin synthesis mainly reflects end-stage liver disease, intestinal malabsorption syndromes and protein calorie malnutrition. Nephrotic syndrome and severe burns are the examples of Nephrotic syndrome and severe burns are the examples of albumin loss. The consequences of a decrease in serum albumin result in a shift of fluid from the intravascular to the interstitial space, resulting in intravascular volume depletion and oedema formation [21].

The present study showed low level of the globulin in patients group when compared to control group. This result is similar to other study presented [29].The globulin fraction includes hundreds of serum proteins including carrier proteins, enzymes, complement, and immunoglobulins. Most of these are synthesized in the liver, although the immunoglobulins are synthesized by plasma cells, Malnutrition and congenital immune deficiency can cause a decrease in total globulins due to decreased synthesis [29]. The present study suppose that the low levels of the serum transport proteins indicate catabolic protein status in children with ALL during early weeks of therapy.

The mean levels of sera TAA showed A significant decrease in patients group when compared to control group $(\mathrm{P}<0.001)$, while
AOPP,NSMCE2 , NSMCE2 /TAA ratio, and NSMCE2 /S .Protein ratio, AOPP/TAA ratio and AOPP/S. Protein ratio showed a significant increase in patients group in comparison to control group $(\mathrm{P}<0.001)$ as shown in table 3 and figure 1.

The decrease in TAA indicates a lack of balance between elevated ROS generation and antioxidant capacity, which is inefficient. This situation can lead to deteriorated function of different organs[30]. Advanced oxidation protein products (AOPP) are one of the biochemical parameters indicative of oxidation stress. AOPP are proteins, predominantly albumin and its aggregates damaged by oxidative stress [31]. AOPPs result from the action of chlorinated compounds on proteins, leading to the formation of di tyrosine residues and consequently to the protein crosslinking, aggregation and precipitation. Except for being the effect of oxidative imbalance, AOPPs are involved in the further development of oxidative stress and inflammation by the activation of immune cells $[8,31]$ in this study show increase level of AOPP in patients group when compared to control that's support the notion that free radical reactions may be increased in malignant cells.

The current study showed that there were no significant different in serum TAA, AOPP,NSMCE2, NSMCE2 /TAA ratio, and NSMCE2 $/ \mathrm{S}$. protein ratio, AOPP/TAA ratio and AOPP/S. protein between male and female patient or when divided patients group according age in two group (18year )and (9-16 year). 
Table (3): The biochemical
parameters of different studied groups (Mean \pm SD)

\begin{tabular}{|c|c|c|c|}
\hline Characteristic & Patients & Control & P \\
\hline S. TAA [mmol/l] & $0.97 \pm 0.16$ & $1.80 \pm 0.37$ & $<0.001$ \\
\hline AOPP [ng/dl] & $98.23 \pm 43.66$ & $57.47 \pm 16.59$ & $<0.001$ \\
\hline NSMCE2 [pg/dl] & $\begin{array}{c}271.60 \\
\pm 109.85\end{array}$ & $133.76 \pm 51.89$ & $<0.001$ \\
\hline $\begin{array}{c}\text { NSMCE2 /TAA } \\
\text { ratio }\end{array}$ & $286.27 \pm 75.17$ & $76.96 \pm 22.40$ & $<0.001$ \\
\hline AOPP/TAA ratio & $101.00 \pm 44.68$ & $33.45 \pm 13.23$ & $<0.001$ \\
\hline $\begin{array}{c}\text { NSMCE2/S.protein } \\
\text { ratio }\end{array}$ & $43.80 \pm 12.55$ & $19.23 \pm 7.62$ & $<0.001$ \\
\hline $\begin{array}{c}\text { AOPP/ S.Protein } \\
\text { ratio }\end{array}$ & $16.19 \pm 3.73$ & $8.25 \pm 2.79$ & $<0.001$ \\
\hline
\end{tabular}

*Significant at 0.05 level of significance

Oxidative stress, measured as reactive oxygen species (ROS), plays an important role in cancerogenesis due to DNA damage and its modification [32] Anticancer treatment, radiotherapy and chemotherapy (i.e. cyclophosphamide, anthracyclines) induce ROS production. This leads to the death of neoplastic cells, but may also influence damage to healthy cells and tissues $[30,33,34]$.

To maintain genomic stability, cells must also be able to cope with DNA damage that occurs both intentionally and unintentionally, including double-strand breaks (DSBs), single-strand breaks, and other types of lesions[35,36]. To prevent
DNA damage from compromising the genetic integrity of an organism, cells employ surveillance mechanisms to sense damaged DNA and to elicit coordinated cellular responses, such as DNA repair[37] the results suggest that hMMS21 and the hSMC5/6 complex play an important role in the repair of damaged cellular DNA. [36].

The E3 SUMO-protein ligase component of the SMC5-SMC6 complex, a complex involved in DNA double-strand break repair by homologous recombination[16,17]. The Smc5-6 complex, which is essential for viability, is required for several aspects of DNA metabolism, including recombinational repair and maintenance of the DNA damage checkpoint.[38]

Down-regulation of the SMC5/6 complex in yeasts and in mammalian cells (this study) renders cells more sensitive to a wide spectrum of DNAdamaging agents[39- 42]. It is possible that the SMC5/6 complex is directly involved in the repair of multiple types of DNA lesions. Because many types of DNA-damaging agents can indirectly lead to the generation of DSBs, it is also possible that a major function of the SMC5/6 complex is the repair of DSB through HR.[36]. 


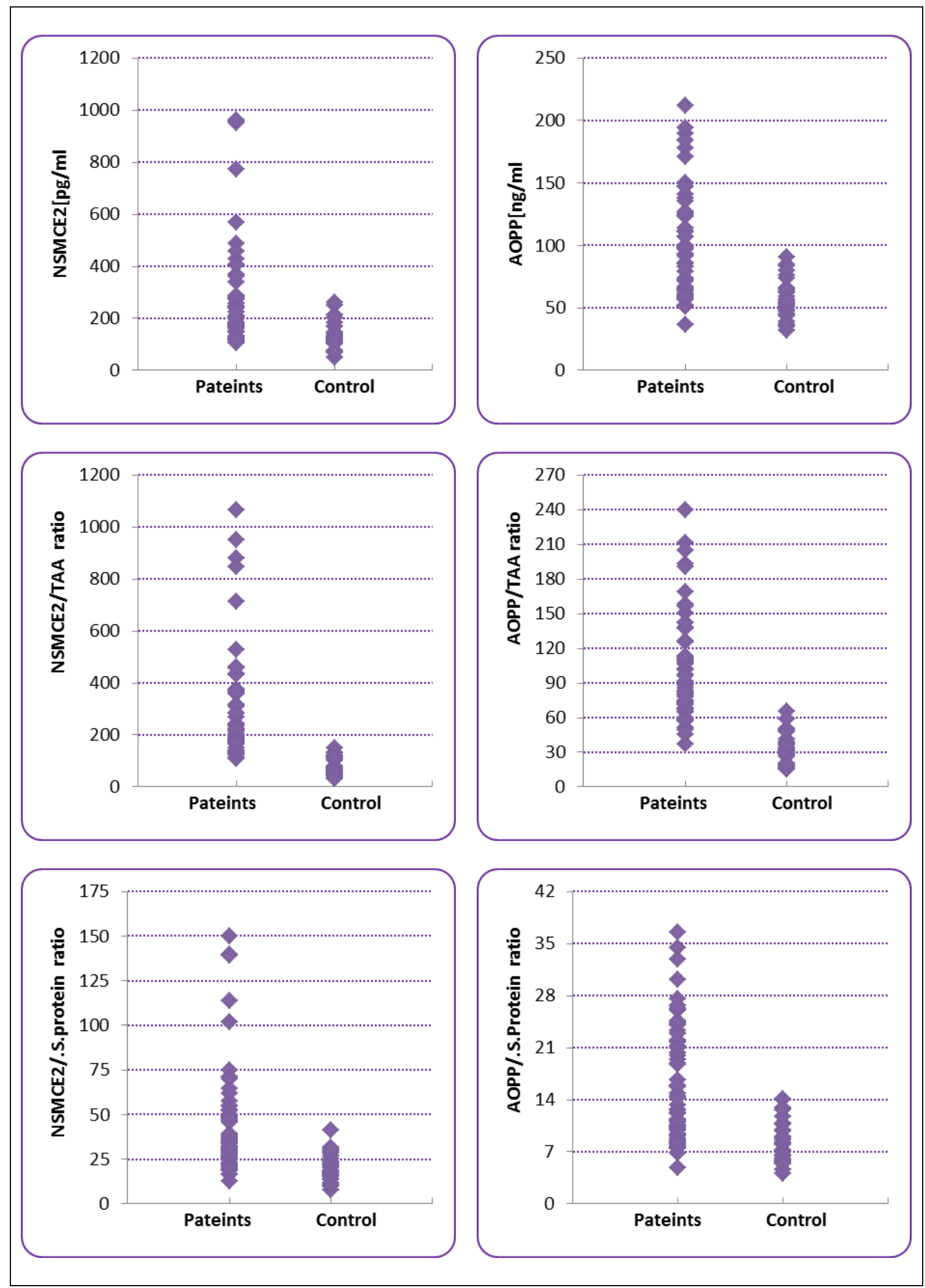

Fig. 1: Mean distribution of biochemical parameters in patients group and control group 
The current study showed increased level of NSMCE2, NSMCE2/S.protein ratio may be due to increased free radicals and oxidative stress factors, which consequently leads to an increase in damage made in the DNA and because of the active role of this enzyme in the treatment of damage made in the DNA. No previous studies have showed these results in Child Acute Lymphoblastic Leukemia. A more detailed research to study the effect of induction therapy on other another antioxidants and connection with NSMCE2 should be conducted.

\section{Conclusion:}

The results from this study showed a significant increase in NSMCE2, AOPP, NSMCE2 /TAA ratio ,NSMCE2/S. protein ratio and AOPP/ S.Protein ratio. These results in the present study are shown for the first time to the best of our knowledge, thus suggesting that these factors may be useful in following improvements in the repair of damaged cellular DNA in subjects with ALL, However, further studies are needed to validate this measure in other populations with this treatment or with consolidation therapy[CNSphase] or in patients treated with maintenance chemotherapy.

\section{Reference}

1- David GT. And Bleyer A. 2004. The leukemias in Nelson Text book of Pediatric ,17th ,Philadelphia, Sounders Elsevier, p 1694.

2- Hoffbrand AV., Moss AH. and Pettit JE. 2006 .Essential Haematology, 5th Ed , 157159:167.

3- Kasper LB. and Fauci S.2005.Harrison's Principles of Internal Medicine, Malignancies of Lymphoid Cells. Clinical Features,
Treatment, and Prognosis of Specific Lymphoid Malignancies, 16th ed. ,Chapter 97, 284-296.

4- El-Sabagh ME., Ramadan KS., Elslam MA. And Ibrahim AM .2011. Antioxidants Status in Acute Lymphoblastic Leukemic Patients, Am J-Med Med sci. 1(1): 1-6.

5- Healy J., Bélanger H., Beaulieu P., Larivière M., Labuda D. and Sinnett D.2007. Promoter SNPs in G1/S checkpoint regulators and their impact on the susceptibility to childhood leukemia ,Blood 109( 2): 683-692.

6- Faderl S., O'Brien S., Pui CH., Stock W., Wetzler M., Hoelzer D. and Kantarjian HM.2010. Adult Acute Lymphoblastic Leukemia Concepts and Strategies, Cancer 116(5):1165-1176.

7- Mera K., Anraku M., Kitamura K., Nakajou K., Maruyama T. and Otagiri M.2005. The structure and function of oxidized albumin in hemodialysis patients: its role in elevated oxidative stress via neutrophil burst, Biochem Biophys Res Commun 334(4):1322-8.

8- Krzystek-Korpacka M., Patryn E., Boehm D., Berdowska I., Zielinski B. and Noczynska A. 2008.Advanced oxidation protein products (AOPPs) in juvenile overweight and obesity prior to and following weight reduction, Clin Biochem 41 : 943-949.

9- Kalousová M., Zima T., Tesar V., Dusilová-Sulková S. and Skrha J.2005.Advanced glycoxidation end products in chronic diseasesclinical chemistry andgenetic background, Mutat Res 579 :37-46.

10- Piwowar A., Knapik-Kordecka M. and Warwas M.2007. AOPP and its relations with selected markers of oxidative/antioxidative system in type 2 diabetes mellitus, Diabetes Res. Clin. Pract 77:188-92. 
11- Krzystek-Korpacka M, Salmonowicz B, Boehm D, Berdowska I, Zielinski B, Patryn E, Noczynska A, Gamian A.2008. Diagnosticpotential of oxidative stress markers in children and adolescents with type 1 diabetes, Clin. Biochem 41(1-2):48-55

12- Ronald TH.2005.SUMO: A History of Modification, Mol Cell 18:1-12

13- Stielow B., Sapetschnig A., Krüger I., Kunert N., Brehm A., Boutros M. and Suske G.2008. Identification of SUMO Dependent Chromatin-Associated

Transcriptional Repression Components by a Genome-wide RNAi Screen, Mol Cell 29(6): 742754.

14- Potts PR. and $\mathrm{Yu}$ H. 2005. Human MMS21/NSE2 is a SUMO ligase required for DNA repair, Mol Cell Biol 25(18) : 7021-7032.

15- Potts PR., Porteus MH. and $\mathrm{Yu}$ H.2006.Human SMC5/6 complex promotes sister chromatid homologous recombination by recruiting the $\mathrm{SMC} 1 / 3$ cohesin complex to double-strand breaks, EMBO J 25:3377-3388.

16- Potts PR. and $\mathrm{Yu} \mathrm{H.2007.The}$ SMC5/6 complex maintains telomere length in ALT cancer cells through SUMOylation of telomerebinding proteins, Nat Struct Mol Biol 14(7):581-590.

17- Behlke-Steinert S., TouatTodeschini L., Skoufias DA. and Margolis RL.2009. SMC5 and MMS21 are required for chromosome cohesion and mitotic progression,

Cell Cycle 8(14):2211-2218.

18- Lowry NJ., Rosebrough AI. and Randall RJ.1951. Protein measurement with the Folin phenol reagent, J Biol. Chem 193: 265275.
19- Rodkey FL. 1965. Direct spectrophtometric determination of albumin in human serum, Clin Chem 11: 478.

20- Ric e -Evans C. and NJ. Mille. 1994. Total antioxidant status in sera and body fluids. In: Meth o ds in Enzymology, New York: Academic Press 279-293.

21- Sheikh N., Abid R., Qureshi AW. and Basheer T.2012. Expression of Low MolecularWeight Proteins in Patients with Leukaemia ,West Indian Med J 61 (3): 235-239

22- Champlin R. and Gale RP. 2002. Acute lymphoblastic leukemia: Recent advances in biology and therapy, Blood 73: 2051.

23- Choi JW. and Pai SH. 2003. Erythropoietic Activities in Acute Leukemia and in Malignant Lymphoma with or without Bone Marrow Involvement, Ann Clin Lab Sci 33(4): 407-410.

24- Suriya OM. and Aleem A.2012.Frank Hematuria as the Presentation Feature of Acute Leukemia , Saudi J Kidney Dis Transpl 21(5) 940-942

25- Halton JM., Atkinson SA. and Barr RD.1998. growth and body composition in response to chemotherapy in children with acute lymphoblastic leukemia, Int J Cancer Suppl 11, 81-84.

26- Khan AU., Sheikh MU. and Intekhab K.2006.Effect of hypoproteinemia on treatment outcome in children with acute lymphoblastic leukemia, J Ayub Med Coll Abbottabad 18(2):53-56.

27- Thomas DA., Cortes J., O'Brien S., Pierce S., Faderl S., Albitar M., Hagemeister FB., Cabanillas FF., Murphy S., Keating MJ. and Kantarjian H.1999. Hyper-CVAD Program in Burkitt's-Type Adult 
Acute Lymphoblastic Leukemia, J Clin. Oncol 17( 8 ): 2461-2470.

28- Gokhale CD., Udipi SA., Ambaye RY., Pai SK. and Advani SH. 2007. Post-Therapy Profile of Serum Total Cholesterol, Retinol and Zinc in Pediatric Acute Lymphoblastic Leukemia and NonHodgkin's Lymphoma J Am Coll. Nutr 26(1) 49-56.

29- McPherson RA.1984.Specific proteins. In: Clinical diagnosis and management, Henry JB, ed. Philadelphia: W. B. Saunders;204214.

30- Krawczuk-Rybak M., Panasiuk A., Czygier M., Muszynska-Roslan K., Wysocka J. and Szmitkowski M. 2012. Total antioxidant status (TAS) in childhood cancer survivors, Folia Histochem Cytobiol 50(3):468-472.

31- Kalousová M., Zima T., Tesar V., Dusilová-Sulková S. and Skrha J.2005.clinical chemistry and genetic background, Mutat Res 579 :37-46.

32- Klaunig JE., Kamendulis LM. and Hocevar BA.2010.Oxidative stress and oxidative damage in carcinogenesis, Toxicol Pathol 38:96-109.

33- Barry HT., David CL, Vivian IF., Jacqueline MH., Elliot JP., Tracie LM. and Steven EL.2011.Anthracyclineassociated cardiotoxicity in survivors of childhood cancer, Pediatr Cardiol 32(3):342-353.

34- Al-Tonbary Y., Al-Hasan SA., Zaki M., Hammad A., Kandil S and Fouda A.2011.Impact of antioxidant status and apoptosis on the induction phase of chemotherapy in childhood acute lymphoblastic leukemia, Hematology 16(1):1-19.

35- Kastan MB., and Bartek J. 2004. Cell-cycle checkpoints and cancer, Nature 432:316-323.
36- Potts PR. and $\mathrm{Yu}$ H.2005. Human MMS21/NSE2 Is a SUMO Ligase Required for DNA Repair, Mol Cell Biol 25(16)7021-7030.

37- Sancar A., Lindsey-Boltz LA., Unsal-Kaçmaz K. and Linn S.2004. Molecular mechanisms of mammalian DNA repair and the DNA damage checkpoints, Annu. Rev. Biochem., 73:39-85.

38- Andrews EA., Palecek J., Sergeant J., Taylor E., Lehmann AR. and Watts FZ.2005.Nse2, a Component of the Smc5-6 Complex, Is a SUMO Ligase Required for the Response to DNA Damage, Mol Cell Biol 25(1) : 185196

39- Hu B., Liao C., Millson SH., Mollapour M., Prodromou C., Pearl LH., Piper PW. and Panaretou B.2005.Qri2/Nse4, a component of the essential Smc5/6 DNA repair complex, Mol. Microbiol. 55(6): 1735-1750.

40- Onoda F., Takeda M., Seki M., Maeda D., Tajima J., Ui A., Yagi H. and Enomoto T.2004. SMC6 is required for MMS-induced interchromosomal and sister chromatid recombinations in Saccharomyces cerevisiae, DNA Repair (Amst) 3:429-439

41- Pebernard S., McDonald WH., Pavlova Y., Yates JR. and Boddy MN.2004. Nse1, Nse2, and a novel subunit of the Smc5-Smc6 complex, Nse3, play a crucial role in meiosis, Mol Biol Cell 15(11):4866-4876

42- Fujioka Y., Kimata Y., Nomaguchi K., Watanabe K. and Kohno K.2002.Identification of a novel non-structural maintenance of chromosomes (SMC) component of the SMC5-SMC6 complex involved in DNA repair, J. Biol. Chem. 277(24): 21585-21591. 


\section{E3 SUMO- تقدير تركيز نواتج الاكسدة العالية البروتين (AOPP) وانزيم Protein Ligase NSE2[NSMCE2] الليمفاوي الحاد}

وسن عادل مهجيث*
الاء شوقي عبل الباري*

* ق قسم الكيمياء، كلية العلوم للبنات ، جامعة بغداد

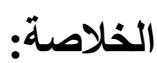

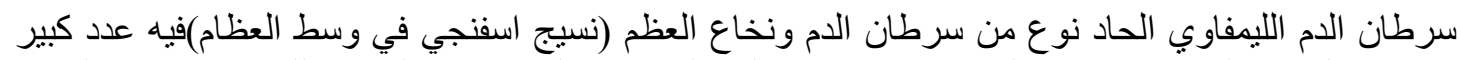

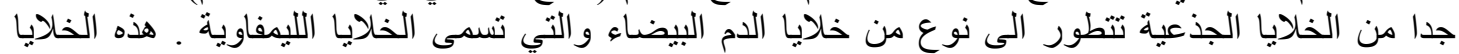

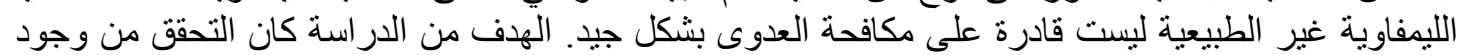

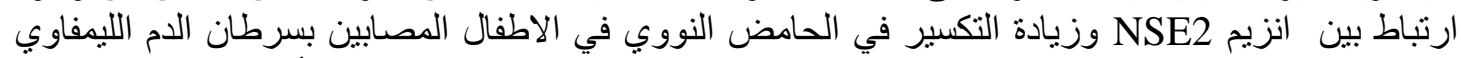

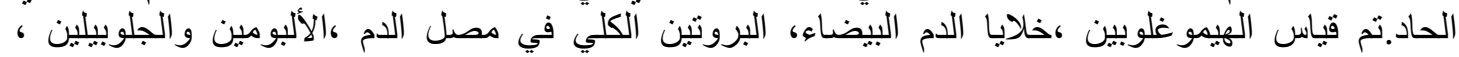

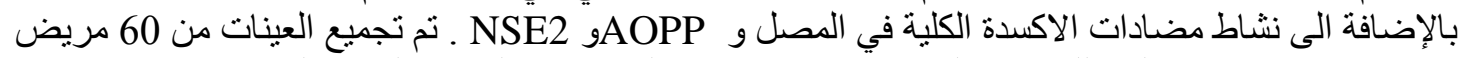

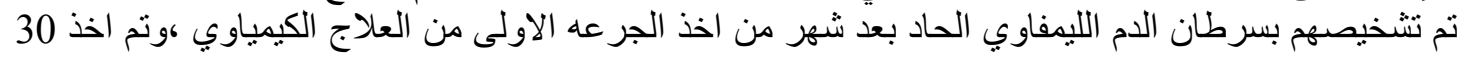

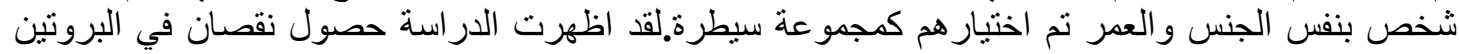

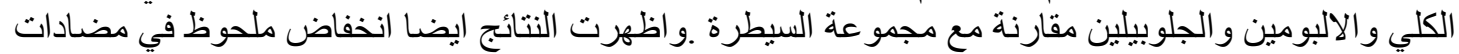

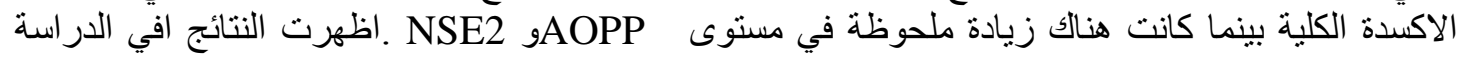

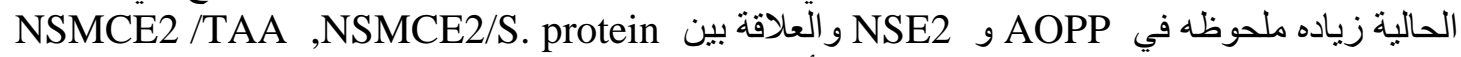

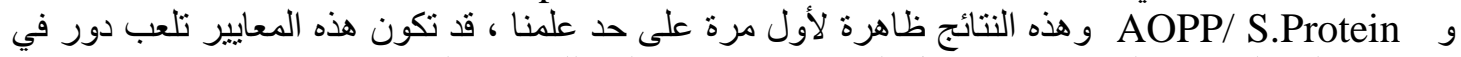

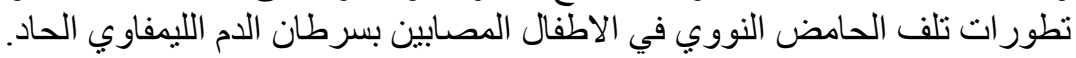

